\title{
Finding the lost years of Jesus ... or not
}

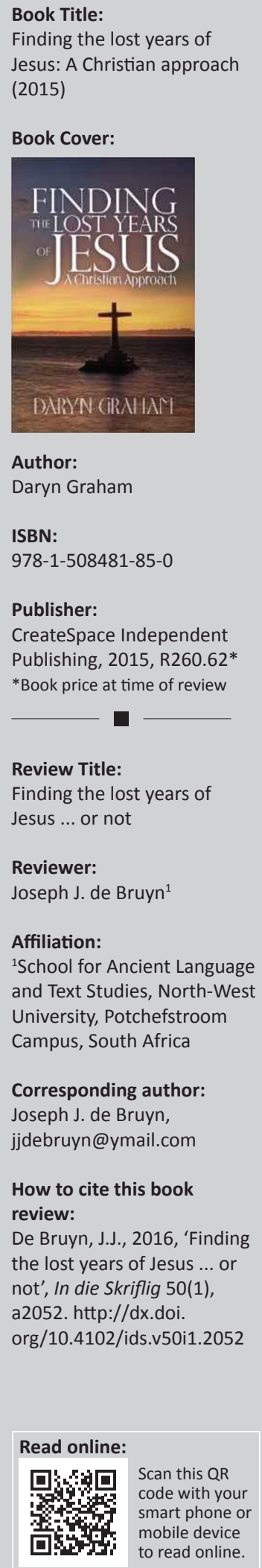

When I was asked to review Daryn Graham's book, Finding the lost years of Jesus: A Christian approach, I was excited. However, sad to say, my excitement was short lived. The reason for my disappointment is that Graham's book is not only extremely fundamentalistic, but the author uses his so called Christian approach to sketch a historical Jesus that is no more improbable than the Jesus figures Graham tries to contradict in the second half of his book.

The book is divided into two parts. In the first half Graham wants to approach the search for a historical Jesus figure by using only the bible text itself. But then he makes himself guilty of eisegesis (forcing things into the texts). Furthermore, the author, in more than one instance, uses a Roman worldview which he forces onto a Jewish community in Palestine; and where he does use a Jewish worldview, he uses one from 400-600 CE and even later, and again forced it onto the Jewish community of 0-33 CE, where the Jewish worldview still very much revolved around the Temple in Jerusalem. The problem with this method is that, even though possible parallels could be made between different worldviews, the author does not regard these possible parallels as theories, but as historical facts, which he then forces into the biblical texts without regard for the context. An example of Graham's eisegesis is inter alia his use of Hebrews 5:8 to 'prove' that Jesus had been disciplined by his parents. Other examples are Isaiah 53, which Graham uses as a picture of how Jesus would have looked as a man; and Daniel 7, which the author wrongfully interprets as part of a Babylonian captivity setting.

Graham's search for the lost years of Jesus leads to nothing more than speculation and an over extending of the text. Graham also uses a psychological reading of the text, which leads to even more speculations. This is best seen in the author's discussion on what knowledge Jesus could have had on the age of 12 (p. 24ff.).

In the second part of his book, Graham interacts with some modern theories on the historical Jesus. This includes discussions on Jesus and his possible connection with Qumran, the Pharisees, social revolution, Egypt, India and Britain. Although I can agree with some of Graham's critique on these theories, I cannot agree with his fundamentalistic viewpoint.

To conclude my review: Graham's book is in my opinion not academic, but rather a fundamentalistic work that can only be used if you are interested in eisegesis. 